Rafidain Journal of Science

Vol. 30, No. 4, pp. 1-10, 2021

DOI: 10.33899/rjs.2021.169972

https://rsci.mosuljournals.com

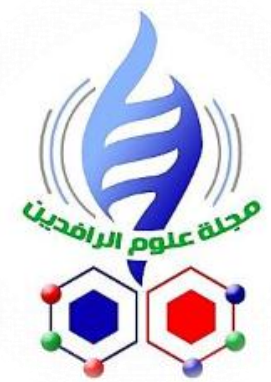

ISSN: 1608-9391

e-ISSN: 2664-2786

Received:4/7/2021

Accepted:6/8/2021

\section{Spectrophotometric Determination of Mebendazole using Diazotization Reaction and Coupling with m-Aminophenol Reagent}

\author{
*Rowa F. Mohammed Farha Kh. Omar \\ Department of Chemistry/ College of Education for Girls/ \\ University of Mosul \\ *E-mail: rowa.gep15@student.uomosul.edu.iq
}

\begin{abstract}
A simple and sensitive spectrophotometric method has been developed for the determination of mebendazole (MBZ) in it's pure and tablet form. The method is based on alkaline hydrolysis of MBZ with sodium hydroxide to give primary amine product which reacts with sodium nitrite in an acidic medium (hydrochloric acid) to yield diazotized mebendazole (D-MBZ) which is coupling with m-aminophenol reagent (mAP) to form an azo dye. The absorbance of the azo dye for this suggested method (yellow dye) has been measured at 360 $\mathrm{nm}$. Beer's law for this proposed method is in the range of $\left(0.5-20 \mu \mathrm{g} . \mathrm{ml}^{-1}\right)$, the molar absorptivity value is $1.63 \times 10^{4}$ L.mol ${ }^{-1} . \mathrm{cm}^{-1}$ and the Sandell's value index is calculated and equal to $0.018 \mu \mathrm{g} . \mathrm{cm}^{-2}$. Also, the limit of detection and the limit of quantification are calculated and equal to 0.1718 $\mu \mathrm{g} \cdot \mathrm{ml}^{-1}$ and $0.5726 \mu \mathrm{g} \cdot \mathrm{ml}^{-1}$ respectively. The ratio of the formed azo dye [D-MBZ: mAP] is [2: 1].
\end{abstract}

Keywords: Spectrophotometric, Diazotization and coupling, Mebendazole, m-Aminophenol reagent. 


\section{INTRODUCTION}

Mebendazole (MBZ) or methyl N-(6-benzoyl-1H-benzimidazole-2-yl) carbamate Fig. (1) is a synthetic benzimidazole derivate and anthelmintic agent used commonly for roundworm (pinworm and hookworm) infections, trichinosis, capillariasis and toxocariasis and other parasitic worm infections by inhibiting the formation of their cytoplasmic microtubules, thereby selectivity and irreversibly blocking glucose uptake. This eventually causes the helminths death (National Center for Biotechnology Information. PubChem, 2021). In recent times, the drug was shown to display promising antitumor activity, especially in cases of colon cancer, medulloblastoma and glioblastoma (Calvo et al., 2016).

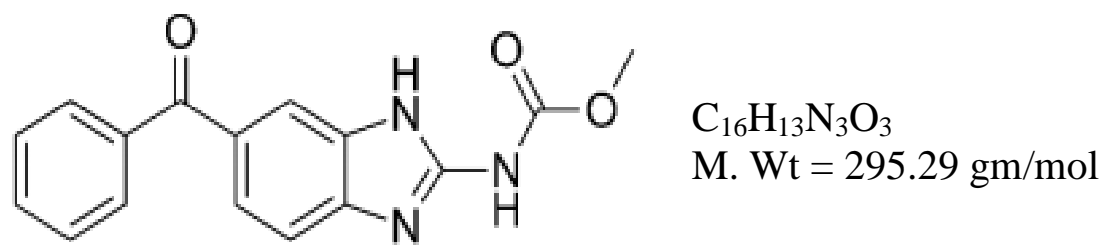

Fig. 1: Chemical structure of mebendazole

Different analytical methods are reported in literature for the assay of mebendazole as free or in its pharmaceutical formulations such as UV-visible spectrometry (Naguib et al., 2020; Murage et al., 2020; Parakh et al., 2015; Swamy and Basavaiah, 2013; Shah et al., 2015; Attia et al., 2015; Delfino et al., 2016), Hyphenated techniques (De Ruyck et al., 2003), RP-UPLC (Prabhu and Maruthapillai, 2021), high performance liquid chromatography (Naguib et al., 2020; YU et al., 2010) and Electrophoresis Method (Xu et al., 2014).

\section{EXPERIMENTAL}

Apparatus:

- Shimadzu UV- 1800 pc UV-Visible dual beam spectrophotometry.

- Quartz cells 1-cm (Cuvettes).

- pH meter type inolab pH 7110.

- Electronic balance type ADAM.

\section{MATERIALS AND SOLUTIONS}

All materials used in this proposed research are of high purity.

1- Stock solution of mebendazole $\left(200 \mu \mathrm{g} \cdot \mathrm{ml}^{-1}\right)$

$0.05 \mathrm{~g}$ of (MBZ) mebendazole was dissolved with $10 \mathrm{ml}$ of $\mathrm{NaOH} 1 \mathrm{M}$ (with heating at boiling point) and the acidity was adjusted to $\mathrm{pH}=7$ with $\mathrm{HCl}$ and completed by distilled water in a volumetric flask to $250 \mathrm{ml}$.

2- Sodium nitrite $\left(3.39 \times 10^{-3} \mathrm{M}\right)$

This solution was prepared by dissolving $0.0234 \mathrm{~g}$ of sodium nitrite in distilled water then transferred into $100 \mathrm{ml}$ volumetric flasks and completed to the mark with distilled water.

\section{3- Hydrochloric acid (1M)}

It was prepared with transfer $8.4 \mathrm{ml}$ of concentrated $\mathrm{HCl}$ into $100 \mathrm{ml}$ volumetric flask and then completed to $100 \mathrm{ml}$ with distilled water.

4- Diazonium salt reagent $\left(3.3910^{-4} \mathrm{M}\right)$

D-MBZ solution was prepared by mixing $50 \mathrm{ml}$ of MBZ (stock solution) with $10 \mathrm{ml}$ of sodium nitrite and $1.5 \mathrm{ml}$ of $\mathrm{HCl}(1 \mathrm{M})$, after shaking well it has completed to the mark with distilled water.

\section{5- m-Aminophenol reagent $(0.1 \%)$}

This m-aminophenol solution was prepared by transfer $0.1 \mathrm{~g}$ of m-aminophenol (mAP) into $10 \mathrm{ml}$ of ethanol and completed to the mark with ethanol in $100 \mathrm{ml}$ volumetric flask. 


\section{6- Potassium hydroxide (1M)}

This solution was prepared by dissolving $5.61 \mathrm{~g}$ of $\mathrm{KOH}$ in distilled water in a volumetric flask and completed to $100 \mathrm{ml}$ with distilled water.

\section{7- Drug solution (Vermox $100 \mu \mathrm{g} \mathrm{MBZ} / \mathrm{ml}$ )}

Three tablets of MBZ (Vermox $100 \mathrm{mg} /$ tablet) (total weight $1.6992 \mathrm{~g}$ ) were crushed together and mixed well then weighing $0.0566 \mathrm{~g}$ of powder and dissolved with $10 \mathrm{ml}$ of $\mathrm{NaOH} 1 \mathrm{M}$ (with heating at boiling point for 5 minutes) and the acidity was adjusted to $\mathrm{pH}=7$ with $\mathrm{HCl}$ then added $10 \mathrm{ml}$ of sodium nitrite $\left(3.39 \times 10^{-3} \mathrm{M}\right)$ and $1.5 \mathrm{ml}$ of $\mathrm{HCl}(1 \mathrm{M})$ and completed to the mark of the volumetric flask $(100 \mathrm{ml})$ by distilled water.

\section{The Procedure and Calibration Curve:}

An aliquot of a sample solution containing $(0.05-2.0 \mathrm{ml})$ of $100 \mu \mathrm{g} \cdot \mathrm{ml}^{-1}$ diazotized MBZ is transferred into a series of $10 \mathrm{ml}$ volumetric flask then $1.5 \mathrm{ml}$ of $(0.1 \% \mathrm{mAP})$ followed by $1 \mathrm{ml}$ of $1 \mathrm{M} \mathrm{KOH}$ then diluted to the marks with distilled water and measured at $360 \mathrm{~nm}$ against blank solution and the results were as in the Fig. (2).

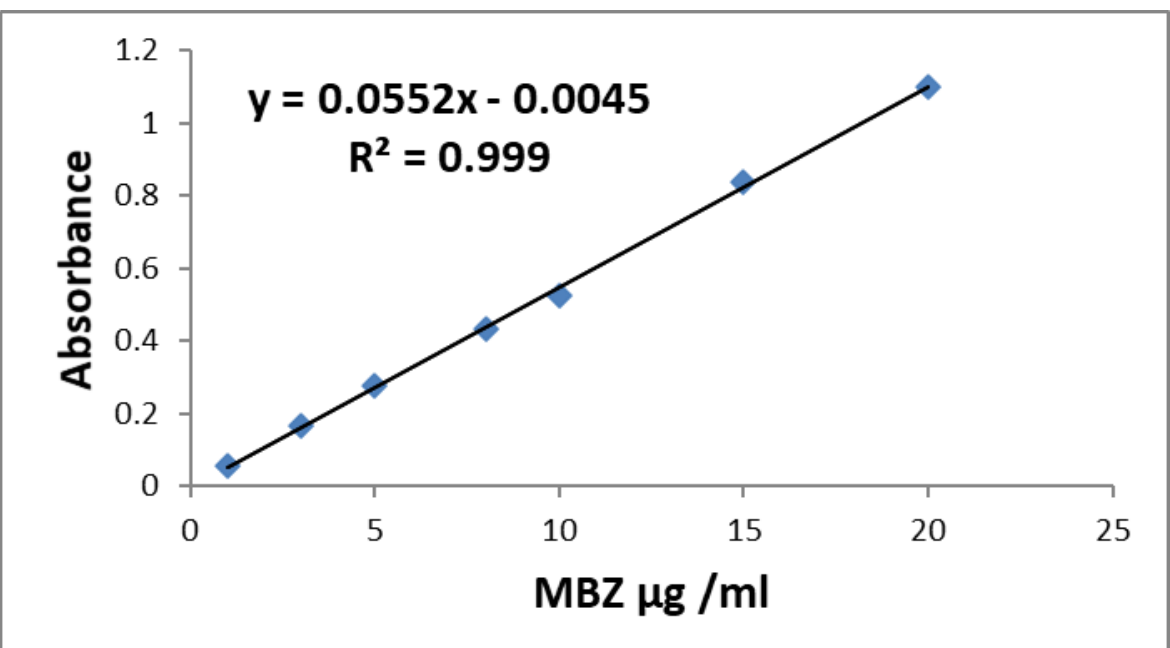

Fig. 2: Calibration curve of MBZ proceed according to suggested method

molar absorptivity and Sandell's index values are calculated and equal to $1.63 \times 10^{4} 1 / \mathrm{mol} . \mathrm{cm}$ and $0.018 \mu \mathrm{g} / \mathrm{cm}^{2}$ respectively.

\section{RESULT AND DISCUSSION}

\section{The Optimum Amount of Hydrochloric Acid:}

Different amount of 1M HCL solution $(0.5-2.0 \mathrm{ml})$ has been studied. $1.5 \mathrm{ml}$ of $\mathrm{HCl}$ was enough to obtain a maximum absorbance.

\section{The Effect of Temperature on Diazonium Salt:}

The effect of temperature was studied at a various temperature on the diazotization of MBZ (see the results in Table 1).

Table 1: Effect of temperature on diazonium salt.

\begin{tabular}{|c|c|c|c|}
\hline Temperature, $^{\mathbf{0}} \mathbf{c}$ & $\mathbf{0}$ & $\mathbf{5}$ & Room temperature (25 $\pm \mathbf{2})$ \\
\hline Absorbance & 0.532 & 0.530 & 0.527 \\
\hline
\end{tabular}


From the previous results in (Table 1) the difference in absorbance is small between the different degrees of temperature so and for ease we had chosen room temperature in suffix experiments.

The Suitable Amount of Reagent (mAP):

The suitable amount of reagent was checked and gave the following results.

Table 2: Optimum amount of reagent (mAP)

\begin{tabular}{|c|c|c|c|c|c|c|}
\hline \multirow{2}{*}{$\begin{array}{c}\text { Reagent } \\
(\mathbf{0 . 1 \%}, \mathbf{~ m l})\end{array}$} & \multicolumn{5}{|c|}{ Absorbance/ $\boldsymbol{\mu g . \mathbf { m l } ^ { - 1 }}$ of MBZ } & \multirow{2}{*}{$\mathbf{R}^{\mathbf{2}}$} \\
\cline { 2 - 6 } & $\mathbf{2 . 5}$ & $\mathbf{5 . 0}$ & $\mathbf{8 . 0}$ & $\mathbf{1 0}$ & $\mathbf{1 5}$ & \\
\hline $\mathbf{0 . 2}$ & 0.071 & 0.189 & 0.304 & 0.422 & 0.601 & 0.9951 \\
\hline $\mathbf{0 . 5}$ & 0.096 & 0.202 & 0.339 & 0.452 & 0.645 & 0.9969 \\
\hline $\mathbf{0 . 7}$ & 0.109 & 0.216 & 0.370 & 0.497 & 0.701 & 0.9954 \\
\hline $\mathbf{1 . 0}$ & 0.116 & 0.232 & 0.392 & 0.509 & 0.732 & 0.9979 \\
\hline $\mathbf{1 . 5}$ & 0.127 & 0.251 & 0.404 & 0.529 & 0.762 & 0.9984 \\
\hline $\mathbf{2 . 0}$ & 0.129 & 0.243 & 0.407 & 0.518 & 0.742 & 0.9980 \\
\hline
\end{tabular}

According to the value of determination coefficient in (Table 2). $1.5 \mathrm{ml}$ of the reagent was chosen as an optimum amount for the next experiments.

Selection of the Optimum Type and Amount of Base:

Many types of base has been checked to make certain of the maximum absorbance (Table 3).

Table 3: Selection of optimum type of base

\begin{tabular}{|c|c|c|}
\hline Base (1M, 2ml) & Absorbance & $\boldsymbol{\lambda}_{\max }$ \\
\hline $\mathrm{NaOH}$ & 0.517 & 360 \\
\hline $\mathrm{KOH}$ & 0.530 & 363 \\
\hline $\mathrm{Na}_{2} \mathrm{CO}_{3}$ & 0.503 & 359 \\
\hline
\end{tabular}

According to the results in (Table 3) potassium hydroxide was fixed in the next experiments. The optimum amount of $\mathrm{KOH}$ was tested also and it showed that $1 \mathrm{ml}$ is a suitable amount according to the highest absorbance of azo dye and it in subsequent experiments (Table 4).

Table 4: optimum amount of KOH

\begin{tabular}{|c|c|}
\hline KOH (ml , 1M) & Absorbance \\
\hline 0.2 & 0.527 \\
\hline 0.5 & 0.528 \\
\hline 0.75 & 0.531 \\
\hline 1.0 & 0.533 \\
\hline 1.5 & 0.530 \\
\hline 2.0 & 0.531 \\
\hline
\end{tabular}

\section{Order of Addition:}

The sequence of additives were studied to choose the suitable sequences (Table 5). 
Table 5: Order of additives

\begin{tabular}{|c|c|}
\hline Order of additives & Absorbance \\
\hline I: $\mathrm{MBZ}+\mathrm{R}+\mathrm{OH}^{-}$ & 0.534 \\
\hline II: $\mathrm{MBZ}+\mathrm{OH}^{-}+\mathrm{R}$ & 0.526 \\
\hline III: $\mathrm{R}+\mathrm{OH}^{-}+\mathrm{MBZ}$ & 0.522 \\
\hline
\end{tabular}

From the previous results the order (I) has been chosen for the next experiments because of its high absorbance.

The stability of Azo Dye with Time:

Effect of time on the azo dye has been studied and the result showed that the dye is stable for at least 60 minutes and the result illustrated in (Table 6).

Table 6: The stability of azo dye

\begin{tabular}{|c|c|c|}
\hline Time & \multicolumn{2}{|c|}{ Absorbance of MBZ $(\boldsymbol{\mu g} / \mathbf{1 0 m})$} \\
\hline & $\mathbf{2 5}$ & $\mathbf{5 0}$ \\
\hline Immediately & 0.137 & 0.279 \\
\hline 5 & 0.136 & 0.277 \\
\hline 10 & 0.136 & 0.277 \\
\hline 15 & 0.135 & 0.276 \\
\hline 20 & 0.135 & 0.276 \\
\hline 25 & 0.135 & 0.276 \\
\hline 30 & 0.135 & 0.275 \\
\hline 35 & 0.134 & 0.275 \\
\hline 40 & 0.134 & 0.274 \\
\hline 45 & 0.134 & 0.275 \\
\hline 50 & 0.133 & 0.274 \\
\hline 55 & 0.133 & 0.274 \\
\hline 60 & 0.133 & 0.274 \\
\hline
\end{tabular}

\section{Absorption Spectra:}

Absorption spectra of a yellow-colored solution (Azo dye) was formed by the coupling of diazotized MBZ with mAP reagent in alkaline medium. This Azo dye has given a maximum absorbance at 360nm against blank solution as shown in the Fig. (3). 


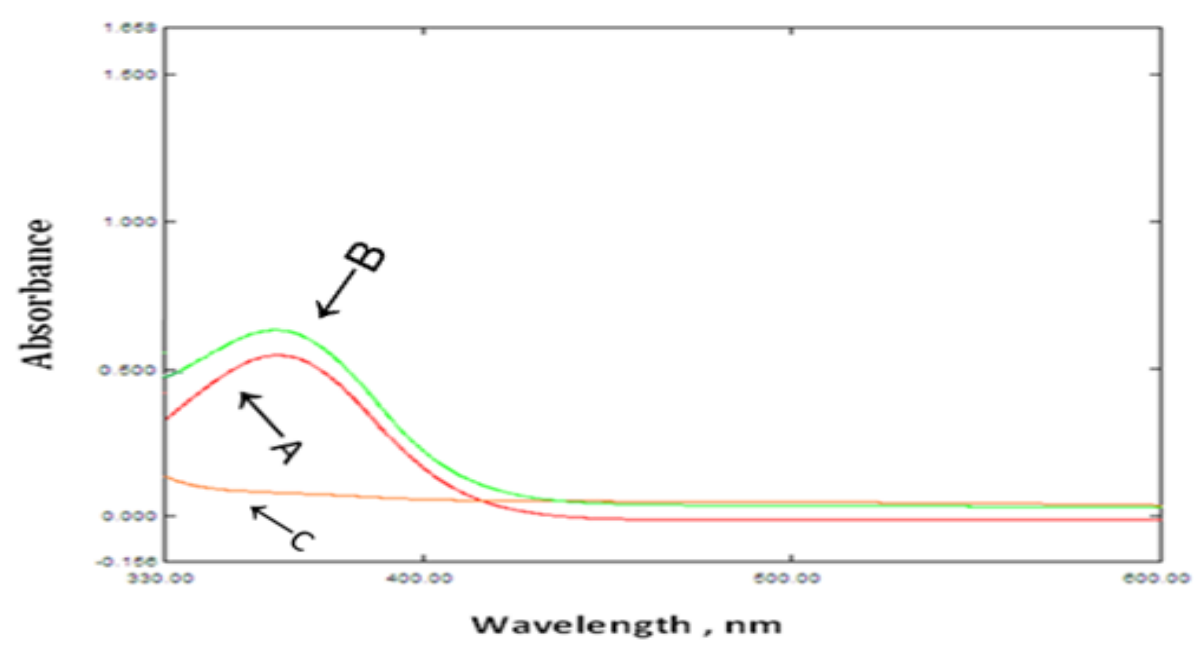

Fig. 3: Absorbance spectra of (A) Azo dye product from proceeding $100 \mu \mathrm{g}$ of $\mathrm{MBZ}$ measured against blank. (B) Azo dye product against distilled water. (C) Blank against distilled water.

\section{The Nature of the Azo Dye:}

The structure of the dye (complex ratio) has been studied using Job's method by preparing a series of volumetric flasks $(10 \mathrm{ml})$ contains different amounts $(0.25-2.75 \mathrm{ml})$ of D-MBZ $\left(3.39 \times 10^{-}\right.$ $\left.{ }^{4} \mathrm{M}\right)$ with a complementary amount $(2.75-0.25 \mathrm{ml})$ of mAP reagent with the same concentration of D-MBZ and finally added $1 \mathrm{ml}$ of $\mathrm{KOH}(1 \mathrm{M})$ for each one of flask and completed by distilled water and measured at $360 \mathrm{~nm}$.

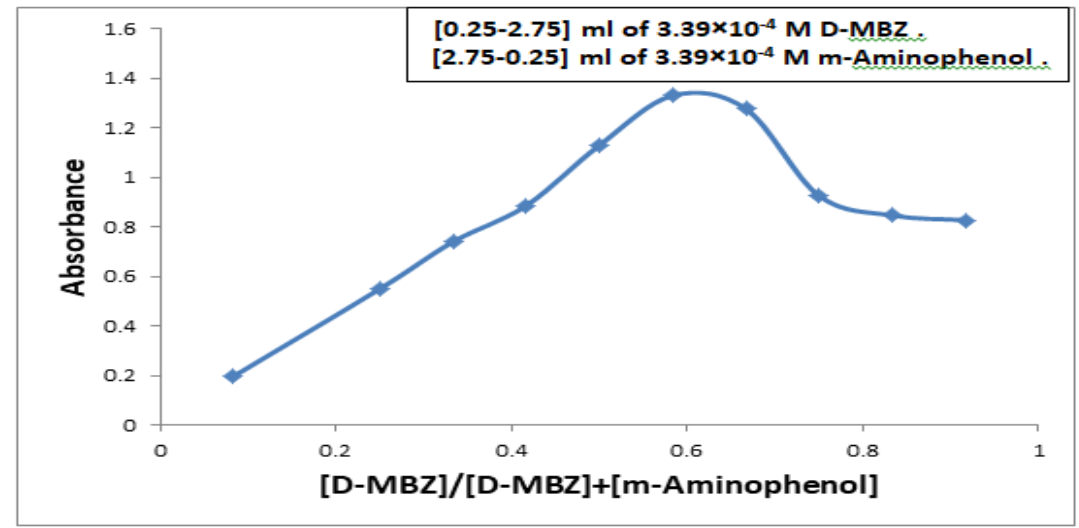

Fig. 4: Job's plot for diazotized MBZ coupled with mAP

From the previous figure we conclude that the ratio of azo dye [D-MBZ: mAP] is [2:1]. The possible reaction path might be written as a follow (Hussin, 2010). 


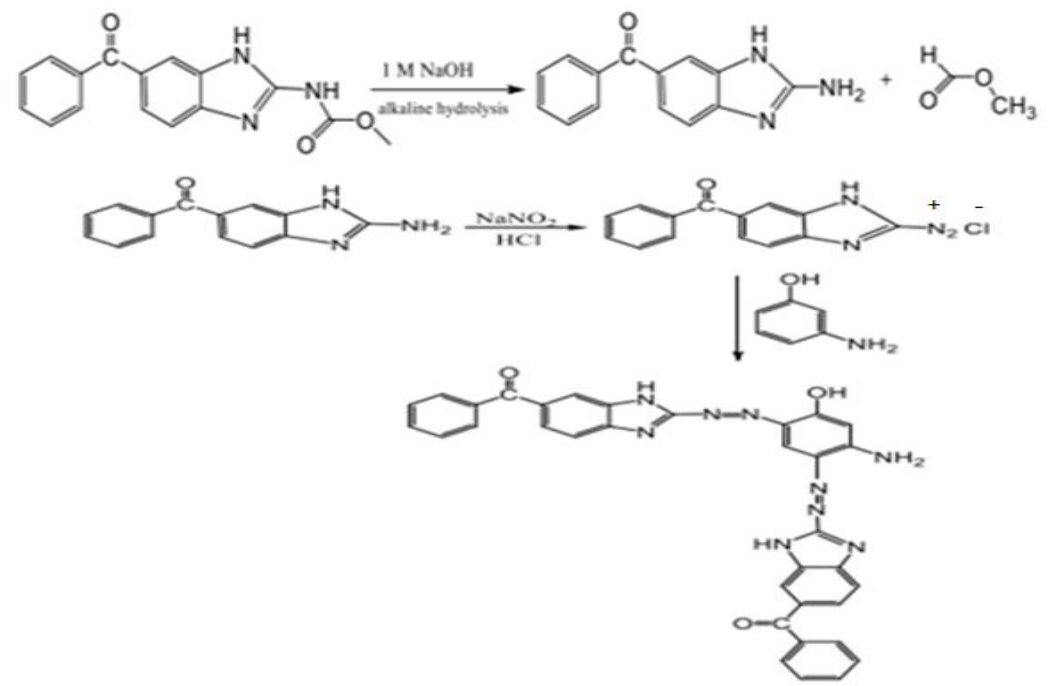

\section{Accuracy and Precision:}

In this study the accuracy and precision has been calculated through the measurements of recovery, percent relative error (RE\%) and relative standard deviation (RSD\%) values by performing five replicates to three concentrations within the calibration curve. The results listed in (Table 7).

Table 7: Accuracy and precision

\begin{tabular}{|c|c|c|c|c|c|}
\hline Sample & $\begin{array}{c}\text { Amount } \\
\text { taken, } \boldsymbol{\mu} \mathbf{g}\end{array}$ & Found, $\boldsymbol{\mu g}$ & RE\% & Recovery \%* & RSD\% \\
\hline \multirow{2}{*}{$\begin{array}{c}\text { Standard Mebendazole solution } \\
(\mathbf{1 0 0} \boldsymbol{\mu} \mathbf{m} / \mathbf{m l})\end{array}$} & 30 & 29.68 & -1.07 & 98.93 & 2.11 \\
\cline { 2 - 7 } & 60 & 60.20 & +0.33 & 100.33 & 1.65 \\
\cline { 2 - 7 } & 100 & 97.13 & -2.87 & 97.13 & 1.23 \\
\hline
\end{tabular}

\section{Application of the Method:}

The application of this suggested method has been performed on tablets of mebendazole pharmaceutical (Vermox $100 \mathrm{mg} /$ tablet) through standard addition method by preparing two series of $10 \mathrm{ml}$ volumetric flasks then added increasing amount $(0-1.2 \mathrm{ml})$ of standard D-MBZ $(100 \mu \mathrm{g} / \mathrm{ml})$ for each one of these flasks and $0.25 \mathrm{ml}$ of drug solution $(100 \mu \mathrm{g} / \mathrm{ml})$ for each flask of the first series flasks and $0.5 \mathrm{ml}$ of the drug for each of the second series flasks then the flasks proceed as mentioned in the standard and curved working method and measured at $360 \mathrm{~nm}$ then it gave the following plot and results.

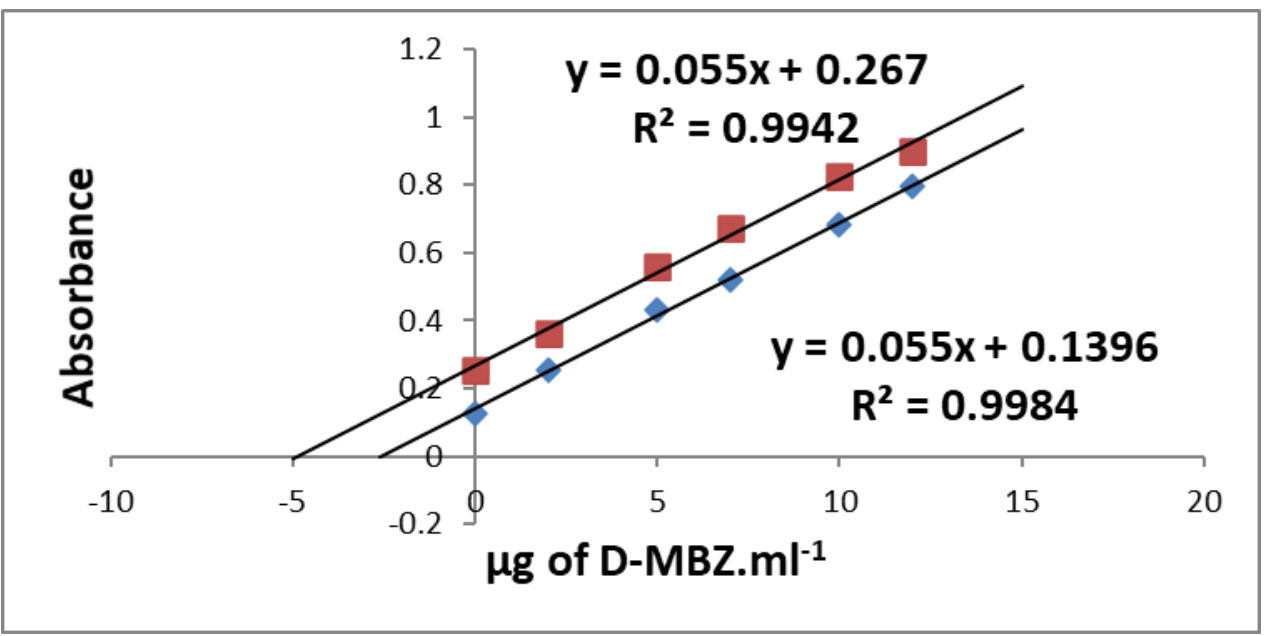

Fig. 5: Standard addition curve of MBZ 
Table 8: Accuracy and precision of mebendazole application

\begin{tabular}{|c|c|c|c|c|c|}
\hline Drug & $\begin{array}{c}\text { Amount } \\
\text { taken, } \boldsymbol{\mu g}\end{array}$ & Found & RE\% & Recovery* & RSD\% \\
\hline \multirow{2}{*}{ Vermox /tablet (JANSSEN) } & 25 & 25.38 & +1.53 & 101.53 & 3.25 \\
\cline { 2 - 6 } & 50 & 48.55 & -2.9 & 97.10 & 1.33 \\
\hline
\end{tabular}

The previous results are very compatible with manufactured drugs results with accepted analytical error.

\section{Comparison of the Methods}

The proposed method was compared to another method from literatures (Table 9).

Table 9: Comparison of mebendazole determination methods

\begin{tabular}{|c|c|c|}
\hline Analytical parameter & Proposed method & $\begin{array}{c}\text { Literature method } \\
\text { (Swamy and } \\
\text { Basavaiah, 2013) }\end{array}$ \\
\hline Type of reaction & Diazotization & Ion-pair \\
\hline$\lambda \max (\mathrm{nm})$ & 360 & 430 \\
\hline Reagent & m-aminophenol & $\begin{array}{c}\text { bromocresole green } \\
\text { dye }\end{array}$ \\
\hline Color of the dye & Yellow & Yellow \\
\hline Molar absorptivity coefficient (L.mole ${ }^{-1} . \mathrm{cm}^{-1}$ ) & $1.63 \times 10^{4}$ & $1.55 \times 10^{4}$ \\
\hline Sandell's sensitivity $\left(\mu \mathrm{g} / \mathrm{cm}^{2}\right)$ & 0.018 & 0.019 \\
\hline Range of determination $\left(\mu \mathrm{g} . \mathrm{ml}^{-1}\right)$ & $(0.5-20)$ & $(1-20)$ \\
\hline Application of the method & $\begin{array}{c}\text { Pharmaceutial preparation } \\
\text { (tablets) }\end{array}$ & $\begin{array}{c}\text { tablets, suspension } \\
\text { and spiked human } \\
\text { urine }\end{array}$ \\
\hline
\end{tabular}

Through the results shown in (Table 9) we conclude that the proposed method includes high sensitivity value of MBZ in its drug sample (vermox tablet).

\section{CONCLUSION}

After studying the optimal conditions for the proposed method and after applying it to the vermox tablets, we conclude that the proposed method has a high degree of sensitivity in addition to good reproducibility, which confirms its success as a reliable method for the determination of mebendazole in its pure form as well as in the form of a medicinal preparation.

\section{REFERENCES}

Attia, K.A.S.M.; Nassar, M.W.I.; El-Dosoky, M.; Madkour, A.W. (2015). Spectrophotometric methods for determination of mebendazole in presence of its alkaline induced degradation products in pure form and pharmaceutical preparation. Ijppr., 4(3), 1-19.

Calvo, N.L.; Kaufman, T.S.; Maggio, R.M. (2016). Mebendazole crystal forms in tablet formulations. An ATR-FTIR/chemometrics approach to polymorph assignment. JPBA. 122, 157-165.

De Ruyck, H.; Daeseleire, E.; De Ridder, H.; Van Renterghem, R. (2003). Liquid chromatographic electrospray tandem mass spectrometric method for the determination of mebendazol and its hydrolysede and reduced metabolites in sheep muscle. Analytica Chimica. Acta., $\mathbf{4 8 3}$ (1-2), 111-123. 
Delfino, M.R.; Monzón, C.M.; Jorge, N.L.; Sarno, M.D.C.T. (2016). Mebendazol spectrophotometric determination. Theorical and experimental study of the interaction with sodium hydroxid. AJST., 7(11), 3948-3953.

Hussin, M.T. (2010). Spectrophotometric determination of nitrazepam by coupling of its diazotized reduced form with m-aminophenol as coupling reagent. RJS., 21(7), 123-140.

Murage, J.K.; Amugune, B.K.; Njogu, P.; Ndwigah, S. (2020). Development and application of a spectrophotometric method in quality evaluation of benzimidazole anthelminthics in Nairobi city county. FJPS., 6(1), 1-7.

Naguib, I.A.; Abdelaleem, E.A.; Hassan, E.S.; Emam, A.A. (2020). Comparative study of ecofriendly spectrophotometric methods for accurate quantification of mebendazole and quinfamide combination; content uniformity evaluation. Spectrochimica. Acta., 235, 118271.

Naguib, I.A.; Hassan, E.S.; Emam, A.A.; Abdelaleem, E.A. (2020). Development and validation of HPTLC and green HPLC methods for determination of a new combination of quinfamide and mebendazole. JCS., 58(1),16-21.

National Center for Biotechnology Information. PubChem Compound Summary for CID 4030, Mebendazole. https://pubchem.ncbi.nlm.nih.gov/compound/Mebendazole. Accessed May 30, 2021.

Parakh, D.R.; Patil, M.P.; Sonawane, S.S.; Jain, C.P. (2015). Developments and validations of Spectrophotometric method for estimation of mebendazol in bulk and pharmaceutical formulation. WJPR., 4(7), 2223-2235.

Prabhu, R.C.; Maruthapillai, A. (2021). New RP-UPLC method development using QbD approach for determination of mebendazole, quinfamide, its impurities and antioxidants in mebendazole and quinfamide fixed dose combinations (FDC). Materials Today: Proceedings., 40, S120-S126.

Shah, U.; Talaviya, T.; Gajjar, A. (2015). Development and validation of derivative spectroscopic Method for the simultaneous estimation of mebendazol and levamisole hydrochloride in pharmaceutical formulations. IJPSR., 2(2), 108-112.

Swamy, N.; Basavaiah, K. (2013). Selective and sensitive assay of mebendazol in pharmaceuticals using bromocresole green by spectrophotometry. Thai. J. Pharm. Sci., 37(4), 171-185.

Xu, L.; Luan, F.; Wang, L.; Liu, H.; Gao, Y. (2014). Development of a capillary zone electrophoresis method for determination of mebendazole and levamisole hydrochloride in a combined tablet and a comparison with a LC method. AOAC International., 97(1), 128132.

YU, H.J.; FENG, B.; JIANG, C.J.; ZHANG, X. L.; HUI, Y.H.; SHEN, X.S. (2010). Determination of residues of mebendazole and its metabolites in fish/shrimp by solid phase extractionhigh performance liquid chromatography. Chinese J. Analysis Laborat., 4, 116023. 


\section{التقدير الطيفي للميييندازول باستخدام تفاعل الأزوتة والاقتران مع الكاشف ميتا-أمينوفينول}

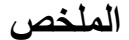

تم وصف طريقة بسيطة وحساسة لتقدير الميييندازول في مركبه الصيدلاني بهيئته النقية وبهيئة كبسول من خلال تفاعل

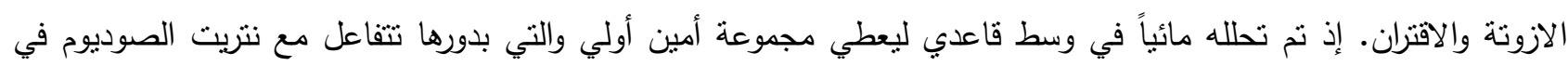
وسط حامضي (حامض الهيدروكلوريك) لينتج عن ذلك ملح الديازونيوم والذي ما يلبث أن يتفاعل مع الكاثف ميتا - امينوفينول في وسط قاعدي ليقترن معه وينتج عنه صبغة الأزو الصفراء اللون والتي تعطي أعلى امتصاص عند الطول الموجي 360 نانوميتر.

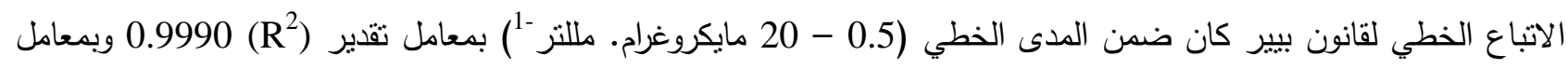

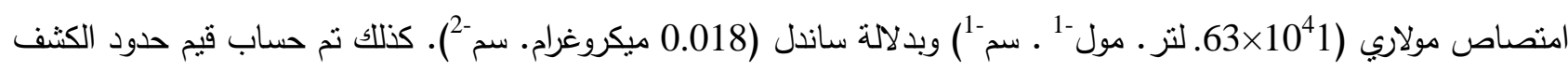

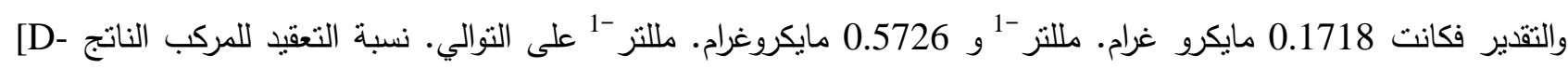
كانت جزيئنين من الميبيندازول المؤزوت إلى جزيئة واحدة من الكاشف ميتا - امينوفينول. الكلمات الدالة: التقدير الطيفي، الازوتة والاقتران، الميبيندازول، كاشف ميتا - امينوفينول. 